\title{
Labor market effects of a work-first policy for refugees
}

\author{
Jacob Nielsen Arendt ${ }^{1}$
}

Received: 11 February 2020 / Accepted: 5 October 2020 /Published online: 23 October 2020

(C) The Author(s) 2020

\begin{abstract}
This study estimates the labor market effects of a work-first policy aimed at speeding up the labor market integration of refugees. The policy added new requirements for refugees to actively search for jobs and to participate in on-the-job training immediately upon arrival in the host country, Denmark. The requirements were added to an existing policy that emphasizes human capital investments in language training. The results show that the work-first policy speeded up entry into regular jobs for men, but they find work in precarious jobs with few hours. Long-run effects are uncertain since the policy crowds out language investments but raises enrollment in education. The policy had no or very small effects for women, which is partly explained by a lower treatment intensity for women.
\end{abstract}

Keywords Refugee · Unemployment · Work-first · Employment support

JEL classification $\mathrm{J} 61 \cdot \mathrm{J} 64 \cdot \mathrm{J} 68$

\section{Introduction}

The large inflow of refugee immigrants that occurred in Europe in 2015 and 2016 emphasized the political and economic challenges that most Western countries face from humanitarian immigration (Zimmerman 2017). ${ }^{1}$ One significant economic

\footnotetext{
${ }^{1}$ The term refugee immigrant covers asylum seekers who have been granted a residence permit either (1) in accordance with the RefugeeConvention, or (2) because of resettlement through the United Nations High Commissioner for Refugees (UNHCR) resettlement program. I use the term here more broadly for short by also including immigrants who are provided subsidiary protection, and immigrants who are reunified with a family member with one of the three previously mentioned terms of protection. See Constant and Zimmermann (2016) for a discussion of the need for European countries to adjust their asylum policies to accommodate recent challenges.
}

Responsible editor: Klaus F. Zimmermann

Jacob Nielsen Arendt

jar@rff.dk

1 The ROCKWOOL Foundation Research Unit, Ny Kongensgade 6, 1472 Copenhagen K, Denmark 
challenge originates from the low employment rate of refugees, even after they have lived for several years in the host country (Bevelander 2016; Bakker et al. 2017; Schultz-Nielsen 2017; Bratsberg et al. 2017; Aaslund et al. 2017; Dustmann et al. 2017; Fasani et al. 2017). The lack of labor market integration clearly constitutes a problem in its own right because of the substantial fiscal costs it generates, but the costs are likely much bigger and broader than the direct fiscal costs (Danzer 2011). For instance, lower levels of economic resources have been shown to increase the level of crime committed by refugees and to reduce schooling outcomes of their children (Andersen et al. 2019; Arendt 2020). Post-displacement living conditions are also correlated with mental health and social participation (Porter and Haslam 2005; Hynie 2018; Laurentsyeva and Venturini 2017). Even though the broader consequences for receiving countries of refugee immigration are poorly understood (Chin and Cortes 2015), they are often misinterpreted in public opinion and therefore generate political tension (Wike et al. 2016; Bell 2016). As I describe below, these findings are particularly disturbing since few causal studies exist that can aid decision makers in their efforts to close the employment gap and thereby reduce the economic pressure, and potentially also the social pressure, that arises as a consequence of the gap.

This study seeks to fill part of the lack of evidence on effective strategies for fostering labor market integration for refugees by estimating the effect of a work-first policy for refugees. A work-first policy is a strategy that emphasizes a quick entry to the labor market and is often contrasted to a train-first policy that emphasizes human capital investments. ${ }^{2}$ The work-first policy considered in this study is constructed as an addendum to a human capital investment strategy, where the refugee is investing in language capital. Denmark adopted the work-first policy in 2016 to address challenges after the recent surge in the number of asylum seekers in Europe. I use a quasi-experimental design to estimate the policy's impact by exploiting the fact that only immigrants who arrived after the third quarter of 2016 were subject to the work-first policy. The work-first policy introduced a requirement that all unemployed immigrants actively search for a job and subjected immigrants to on-the-job training immediately upon their arrival. The aim of the policy was to expedite entry to the labor market, and to avoid skills depreciation and reduced job-finding motivation that may arise with a later job market entry.

Similar strategies aimed at speeding up labor market entry for refugees are in place or are being debated in several countries in the aftermath of the 2015 crisis (Zimmerman 2017). The strategies include early skills-assessment and fast-track solutions for refugees with specific skills in Canada, Sweden, and Germany and discussions about reducing the employment bans during the asylum-seeking period that are in place in many European countries (Martín et al. 2016; Konle-Seidl and Bolitz 2016; Garibay and De Cyuper 2013; Desidero 2016). Marbach et al. (2018) show that asylum seekers' initial labor market experience in a country can have a long-lasting impact. They find that employment bans during the asylum seeker period have large negative long-run consequences for the labor market integration of refugees once they obtain asylum. Descriptive studies have also documented that both the timing of job entry and job entry characteristics may have long-run consequences (Aaslund et al. 2017; Ansala et al. 2018). To my knowledge, no other studies have estimated the causal impact of an

\footnotetext{
${ }^{2}$ An example of a work-first strategy is the US Job-first program, evaluated for instance in Freedman et al. (2000).
} 
intervention that enforces early exposure to the labor market immediately after receiving a residence permit.

The empirical analysis in the current study is based on Danish administrative register data that contain information on all refugees who arrived in Denmark during the period under consideration, including their date of their arrival and weekly information on their participation in labor market programs as well as monthly information on their labor market status. The data allows me to align the timing of program participation with monthly outcomes in a detailed manner. The results show that the work-first policy succeeded in speeding up men's labor market entry: The share of men who has worked one year after arrival increases by 10 percentage points, but they work in precarious jobs with few work hours. I find no indication that men's pay and work industry were affected. The policy crowds out language investments but at the same time raised the share of men who enrolled in education. In contrast, the work-first policy had no or only minor effects for women.

Since I apply a before-after design, care must be taken when interpreting the results. A causal interpretation of the results is supported by findings that show that the results are robust across different specifications, pass two placebo tests, and that the policy works as intended: It sharply raised the share of refugees subjected to job search and who participated in on-the-job training in the first six months following their arrival in Denmark. This increase is smaller for women, and lower treatment intensity can therefore explain part of the smaller results for women.

The results are important because they show that effective quick job-entry strategies are feasible, even in a country with relatively high minimum wages and a generous level of welfare benefits. However, because the work-first policy has ambiguous effects on human capital, it is important to consider the long-run effects of similar policies in future research.

\section{Background}

There is a long academic tradition of comparing work-first policies with human capital policies for the unemployed (Hotz et al. 2006; Card et al. 2018). The two types of policies are expected to affect job finding rates for different reasons. In short, work-first policies are expected to increase job search effort and to reduce search frictions for the unemployed as well as for the employer. For low-skilled, such as many refugees, workfirst policies that include on-the-job training may also provide basic skills that increases productivity. In contrast, human capital policies are expected to boost skills to a higher extent, which may either reduce (due to a higher demand) or prolong (due to increased reservation wages) unemployment periods. Any type of training may prolong unemployment to the extent that it takes time away from general job search (lock-in effects).

General findings in the literature on active labor market policies suggest that a workfirst policy often has a positive, but relatively small, effect in both the short and longer run (Card et al. 2018). In contrast, human capital policies often have negative effects in the short run (the lock-in effects), but it may prove more beneficial in the longer run. These general findings are not easily generalized to refugees, for several reasons. Refugees have experienced difficult circumstances and often possess much less material and mental resources than other immigrants. For instance, it has been documented 
that refugees have worse mental health than other immigrants (Hynie 2018), and an estimated $30-50 \%$ of refugees in Denmark are living with trauma (Rigsrevisionen 2018). Refugees are also often less educated than natives and other immigrants. While $40 \%$ of the refugees in Scandinavia have low education levels, this is only the case for $20 \%$ of other immigrants (Liebig and Tronstad 2018). It is therefore to be expected that they react differently to employment policies than host-country nationals and other immigrants. On the one hand, early labor market support may be beneficial for some refugees because it helps retain their motivation and prevents further deterioration of their human capital. On the other hand, the refugee's substantial skill deficit, both with regard to host-country language skills and academic skills, warrants a larger initial investment. Therefore, there exist a potential trade-off between adaption of a human capital policy and a work-first policy.

A small but growing literature examines the effects of active labor market policies specifically for refugees. ${ }^{3}$ Aaslund and Johansson (2011) examined the effect of intensified coaching in Sweden and found no employment effect of the program. Joona and Nekby (2012) examined the impact of reducing the caseload for caseworkers at job centers in Sweden and found that this raised employment levels for men, but not for women. Joona et al. (2016) examined the impact of the Swedish Establishment Reform, the objective of which was to centralize the active labor market program within the Public Employment Service and provide intensified early coaching to unemployed individuals. Joona et al. (2016) found positive employment effects of the establishment reform for both men and women. Clausen et al. (2009) found that subsidized employment had a positive impact on the transition from unemployment to self-support for newly arrived refugees in Denmark, whereas other types of on-the-job training and classroom training had no such effects.

While the abovementioned studies include interventions that emphasize on-the-job training or job-support that may help alleviate search frictions and provide basic skills, a few studies have also looked at interventions with a larger emphasis on human capital investments. Clausen et al. (2009) found that language training in the introduction program postpones labor market entry. This is supported by Lochmann et al. (2019), who found a positive effect on labor force participation but no effects on earnings and employment for refugees from participation in language courses in France. Looking at immigrants more generally, Hayfron (2001) found no effects on earnings of participation in language training in Norway. A few studies have found positive employment effects of participation in language training for immigrants in general in the longer run (Kennerberg and Aaslund 2010; Orlov 2017). The results suggest that the negative impact of language training found for refugees in the short run may be caused by a lock-in effect, and that language investments are crucial in the longer run. ${ }^{4} \mathrm{~A}$ similar conclusion is found in two studies that considered major reforms of introduction programs for refugees in Finland and Denmark. While the Finnish study attributes the effect to more intensive participation in language training (Sarvimäki and Hämäläinen 2016), the Danish study shows that the effect arises from an expansion of the language course in the introduction program by $30 \%$ (Arendt et al. 2020).

\footnotetext{
${ }^{3}$ A related literature examines the impact of policies that distribute refugees across the country at arrival and of the local labor market in which the refugees arrive (Edin et al. 2003; Damm 2009; Fasani et al. 2017).

${ }^{4}$ A much larger literature has examined either the effect of language proficiency on labor market status or the effect of participating in language training on language proficiency, see Chiswick and Miller (2014) for a review.
} 


\subsection{Institutional setup}

Because the study considers newly arrived refugees I briefly describe the most relevant institutional settings that affects refugees when entering Denmark. I use the term refugee to describe an immigrant with asylum in accordance with the Refugee conventions, the UNHCR quota agreements, or immigrants who receive subsidiary humanitarian protection. The far majority of refugees applies for asylum when already in the country. In such cases, the applicant waits for the asylum decision in asylum camps, and the waiting time in 2015-16 was around 6 to 12 months (Hvidfeldt and SchultzNielsen 2017). Once granted residence, refugees and their family members usually move within a couple of weeks from the asylum camps to public housing provided by local municipalities across the country. The refugees are eligible for welfare benefits once they are settled in a municipality and must be offered participation in an introduction program within the first whole month after residency has been obtained. I describe this program in some detail below, since the work-first policy was implemented as part of the introduction program. Henceforth, I use the term arrival as the point in time where they have settled in a municipality after receiving residency.

Settlement across municipalities is determined by a public dispersal policy. There are 98 municipalities in Denmark, where 91 have more than 20,000 inhabitants, but are geographically relatively small. This dispersal policy allocates refugees based on quotas determined by the number of immigrants from non-Western countries already in the municipality. The dispersal policy entails that immigrants do not settle in places determined by labor market options, and the asylum procedures entail that the decision to immigrate to Denmark was in most cases taken long before the work-first policy was decided upon (as described below). The procedures therefore effectively turn off two selection mechanisms often present in migration studies.

The introduction program has existed since 1999 and hence, because of the dispersal policy, all municipalities have a long history and experience with implementation of the introduction program. Participation in the introduction program is strongly incentivized: If refugees decline the offer or fail to participate in parts of the program, they may be sanctioned financially. Participation in the program is also required if the refugee is to obtain permanent residence. The introduction program comprises an extensive Danish language course corresponding to 1.2 years of full-time participation and different types of employment support (Act no. 474 1998). The participants in the language course are allocated to one of three levels, determined by their prior schooling level. While most refugees initiate their Danish course upon arrival, it can be postponed until at most five years after arrival (Consolidated Act no. 772 2015).

Employment support in the introduction program can either be in the form of on-thejob training, classroom training, and other training (a mixed group of courses ranging from job search courses to courses in health coping and social skills training). On-thejob training either takes the form of subsidized employment or shorter internships at private or public workplaces, which last up to 13 weeks. ${ }^{5}$ The refugee is not paid when training takes place as an internship but continues to receive welfare benefits.

The type of employment support that is provided is based on an assessment of the employability of the refugee, i.e., whether they have the skills and the ability to find and

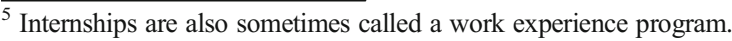


keep a job within a short span of time. The assessment of employability is also called the job readiness assessment, and it plays a pivotal role in the work-first policy. The job readiness assessment must be conducted every third month by the municipal job center caseworker. Refugees who are assessed to be ready to work must actively search for a job and participate in active labor market programs when required to. Moreover, they are required to post their resumé on a public job database and to log their job search. Refugees who are assessed as not being ready for employment are not subject to the same job search and activation requirements.

\subsection{The work-first policy}

The work-first policy considered in this study is made up of two components, which I refer to as the job-search requirement and the on-the-job training requirement. The work-first policy was part of an agreement between the Danish government, municipalities, trade unions, and employer organizations. The agreement was made in March 2016 and its primary purpose was to expedite entry into the labor market. The work-first policy proposal was announced in May, passed by Parliament in June, enforced by law in July 2016, and applied to refugees that received residency in Denmark after 1 October 2016 (Consolidated Act no. 665 2016). ${ }^{6}$

Given that the waiting time for asylum was around 6-12 months during the period (Hvidtfeldt and Schultz-Nielsen 2017), all the refugees in the study are therefore already in the country when the policy is announced.

The job-search requirement states that all participants in the introduction program must be treated as being job ready from the time of their arrival. Before October 2016, immigrants could be declared as not job ready if they had language barriers (which obviously was the case for the majority of immigrants), or if they were unable to log on to the public job database to post their $\mathrm{CV}$ and document their job search, as required. Therefore, only around 5\% were declared job ready under the old regime. These exemptions were explicitly ruled out by the work-first policy, which raised the share declared as job ready to $60-80 \%$ in the quarter upon arrival. The on-the-job training requirement states that on-the-job training should be initiated within one month upon arrival and it is encouraged to start within two weeks. The on-the-job training requirement also states that periods without job training must not exceed 6 weeks. The requirement replaced a more general participation requirement without referral to a specific type of activity. In practice, the general participation requirement was often fulfilled by participation in language training (Bolvig and Arendt 2018). It was not the intention that job training should replace participation in the language course, but rather that participation in language training and job training should take place

\footnotetext{
6 There were other aspects of the introduction program that was altered during the same process, but they were implemented for all cohorts in the introduction program from July 2016, i.e., both the treated and the controls in the current setup (see the next section). To align the program with the new focus on immediate job-search and training, the duration of the program was shortened from three years to one year. However, if the participant has not found employment or begun an ordinary education program, the program is extended for up to five years. Another aspect that changed in July was that that it was obligatory to conduct a health examination before July, whereas after July, the health examination was targeted to those judged to be in need thereof. From July, it also became a requirement for municipalities to delegate the responsibility for the introduction program to a specific public management department, whereas the responsibility could have been split by different departments before.
} 
simultaneously. The participant is therefore only required to work for at least $15 \mathrm{~h}$ a week when participating in job training and the municipality is required to offer language courses in flexible schedules, e.g., during evenings. This leaves time for simultaneous job training and language course participation.

The cohorts who arrived earlier than October 2016 were also subject to the job search and job training requirements, but at a later point in time after their arrival, when their job readiness was reassessed (as it should every third month) after October 2016. The work-first policy therefore shifted the focus from initial human capital investments through language training combined with later job search and on-the-job training to a program that emphasizes immediate job search and on-the-job training simultaneously with language training.

\subsection{Data}

I use register data collected by Danish public agencies for administrative purposes that contain information about labor market outcomes, type of residence permit, time of first arrival, country of origin, gender, age, Danish course level, and household composition at arrival.

The data includes full populations, and I subtract all adults aged 18 to 64 who are either refugees or family members reunified with a refugee. I only include cohorts who arrived in Denmark for the first time from January 2016 to June 2017, i.e., between nine months before and after October 2016. I remove individuals who have received welfare benefits more than one month prior to the arrival. The final sample consists of 9250 individuals of which 4485 are men. $^{7}$

I use information on welfare benefit receipt and active labor market program participation collected on a weekly basis by the Danish Agency for Labour Market and Recruitment (STAR). The main labor market outcomes are monthly records of employment, work hours, and pre-tax labor income, which is obtained from official tax records. Employment is measured by an indicator of a positive amount of labor income in a given month, and labor income excludes the compulsory labor market pension payments and fringe benefits. I set employment, work hours, and labor income to zero in months with subsidized employment, because it is part of the treatment.

Table 1 shows the average characteristics for the analysis sample by gender and treatment status, i.e., whether they arrived before or after October 2016. The numbers in the table show that the treatment and control groups are very similar for given gender in terms of their demographic characteristics (children, age, and whether arrived as a couple), residence permit, and the level of the language course they enroll in, but that the country of origin changes over the period as a majority of the Syrians were admitted before October $2016{ }^{8}$ Therefore, even though several characteristics are significantly different, only country of origin is significant in a regression on the treatment dummy for males, when controlling for remaining covariates. There are larger differences

\footnotetext{
${ }^{7}$ This number can be compared to the official numbers from Statistics Denmark. They include the age range 15-64 years old; there were 9395 persons who received asylum or were family reunified to a refugee, and also slightly more than half are women. Source: Table VAN77KA, https://www.statistikbanken.dk/

${ }^{8}$ The second largest group is from Eritrea and $81 \%$ are either from Eritrea or Syria. The remaining population are from many different countries with Iran as the largest, followed by Afghanistan, Iraq, and Somalia as the only countries with more than 100 persons.
} 


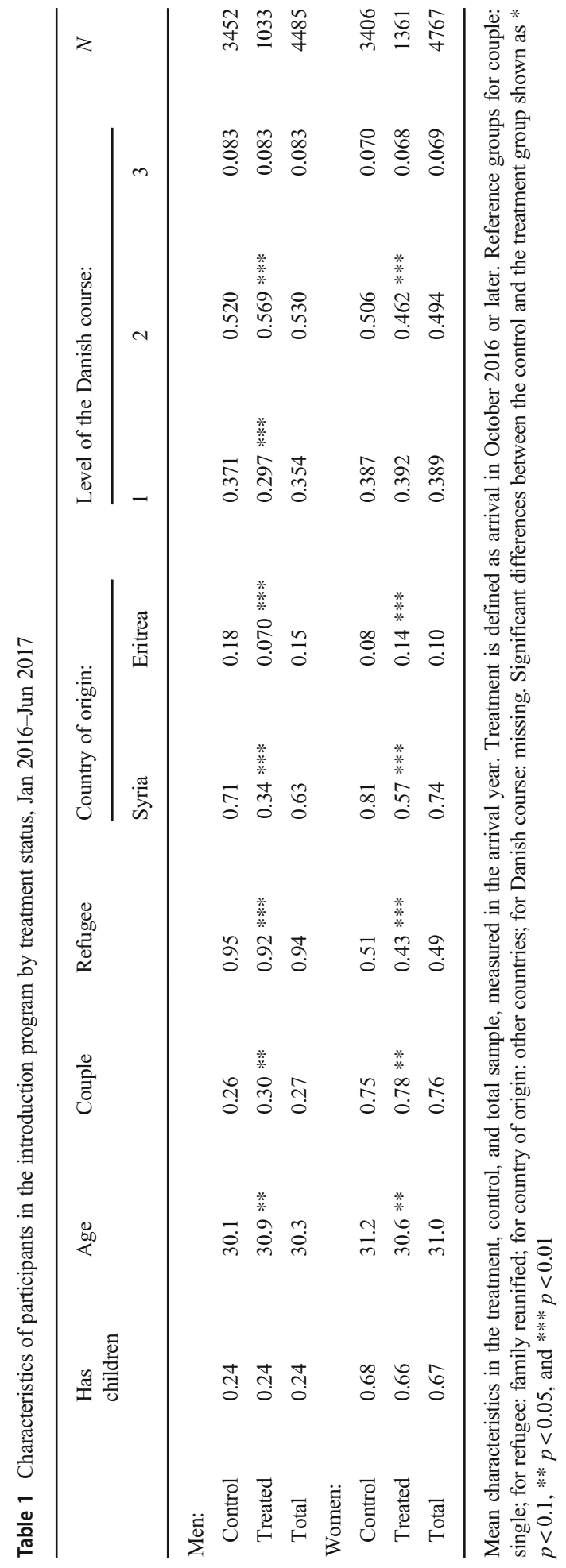


between men and women, because more single men have arrived during the period, and the women are more often reunified to a male spouse with refugee status. The differences between men and women are not a concern for the empirical analyses because they are conducted for men and women separately.

There are several reasons why the differences in characteristics for given gender do not seem to be a cause of concern either. First of all, I observe the share admitted to different Danish course levels. This is important because admission is based on prior educational background, and I therefore control for an important proxy for skill level at arrival. Second, I show later that the absence or presence of effects are found across subgroups, e.g., Syrians and non-Syrians or whether admitted to Danish course 1 or a higher level.

\subsection{Empirical model}

I estimate the effects of the work-first policy by a before-after design using the following linear model, which is estimated separately for each month after arrival:

$$
Y_{i s}=\alpha+\beta_{s} T_{i}+\gamma_{1} t_{i s}+\gamma_{2} t_{i s}^{2}+\pi X_{i}+\theta_{m}+\epsilon_{i s}
$$

Where $Y_{i s}$ is the outcome of interest for person $i$ in the $s^{\text {th }}$ month after arrival. $T$ is the treatment indicator for individuals arriving from October 2016. $X$ contains the following individual characteristics at arrival: country of origin, age, marital status, couple status and number of children in the household, and the level of the Danish course. $\theta_{m}$ are fixed effects for the municipality at arrival.

The estimated coefficient $\beta_{s}$ can be interpreted as an intent-to-treat effect of the work-first policy relative to a counterfactual where the previous policy applies until the control group is assessed for their job readiness after October 2016. Since job readiness is required to be assessed every third month, the control group is assessed under the new rules at the earliest after 3 months, and at the latest after 12 months. Although the intent-to-treat approach depends on the overall level of implementation of the workfirst policy, the advantage is that the estimated effects are unaffected by local variation in the implementation of the work-first policy or local variation in job opportunities. A causal interpretation can be given when, given $X$, arrival cohorts are identical (eliminating cohort effects beyond observed characteristics), when calendar time affects everyone equally, and when there are no anticipation effects. These are not innocuous assumptions, and sensitivity analyses are therefore conducted to assess their importance.

To disentangle the treatment effect from a calendar time effect, I control for calendar time, $t$. To pre-view the general time trend, Fig. 1 shows the development of the employment rate relative to 2013 during the period of observation for ethnic Danes and for immigrants from non-Western countries. ${ }^{9}$ It shows a quadratic development that takes off in 2014 for Danes, whereas immigrants are not affected until 2016, which

\footnotetext{
${ }^{9}$ I show employment for immigrants from non-Western countries because Statistics Denmark do not provide official employment statistics by type of residence permit. Western countries are defined by Statistics Denmark as the EU, Andorra, Iceland, Liechtenstein, Monaco, Norway, San Marino, Switzerland, the Vatican, Canada, USA, Australia, and New Zealand. Non-Western countries include all other countries.
} 


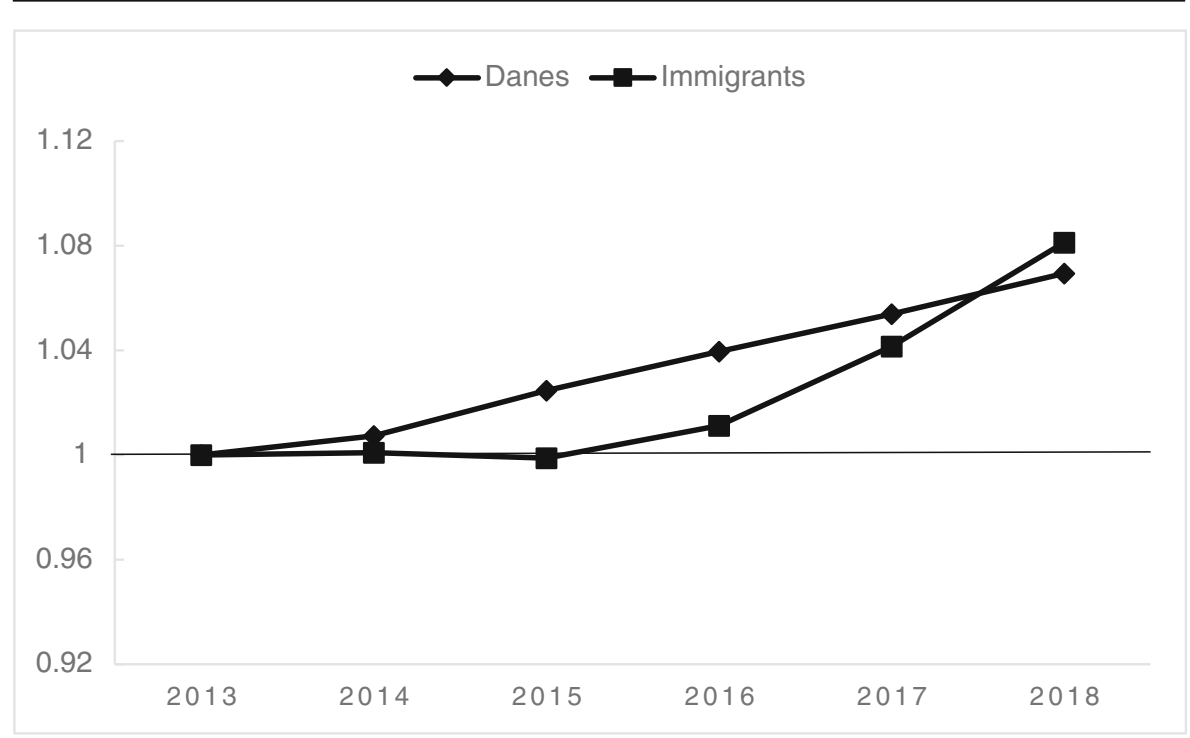

Fig. 1 Employment for immigrants and natives during the observation period $(2013=1)$. Number of employed divided by population size for persons ages 15-69, relative to 2013. Immigrants are from nonWestern countries. Source: www.statistikbanken.dk, Table RAS311, FOLK1C

therefore could be due to the improving economy or the policy. To capture a potential effect of the improving economy seen for the ethnic Danes, I use a quadratic specification in calendar time as the main specification. The robustness towards this choice is later examined and evaluated by statistical fit criteria.

\section{Results}

The main purpose of the work-first policy is to speed up entry into the labor market. I therefore start by presenting the estimated effect from model (1) with monthly outcomes that takes value one if the refugee has worked at some point in time up to and including this month. Figure 2 presents the results separately for men and women. The left part of Fig. 2 shows that the work-first policy increases the share of men who has been employed nine months after their arrival by five percentage points, and that the effect rises and levels out around 10 percentage points after a year onwards. This is an increase of around a third relative to the mean level in the control group. The right part of Fig. 2 shows that the effect on the share of women who has worked is negative, but small and insignificant.

I present results for additional outcomes in Tables 2 and 3 for men. Results for women are small and insignificant and are found in Appendix Tables 7 and 8. Table 2 shows that the effects on hours worked, labor income, and employment in a given month are large and significant 9, 11, and 13 months after their arrival, but that the effect drops thereafter and becomes insignificant. The men who are subjected to the work-first policy earn DKK 1300-1500 per month (USD 200-230) more than the control group nine to 13 months after their arrival. This is an increase of $45-77 \%$ relative to the mean in the control group, which is shown in the rows below the effects. The relative effect on work hours is of the 

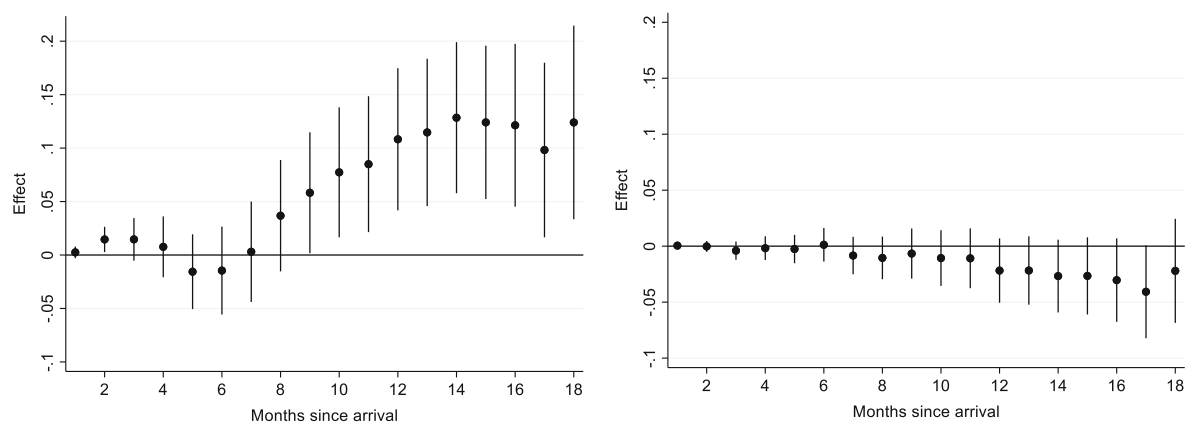

Notes: Estimates of the effects from model (1), with the controls as in Table 2.

Fig. 2 Effects of the work-first policy on the share who has worked (men, women). The dots are estimates of the effects from model (1), with the same control variables as in Table 2 . The vertical bars are $95 \%$ confidence intervals

same size, whereas the effects on employment rates are a bit smaller, but still substantial: The employment rate is $46 \%$ and $32 \%(0.05 / 0.11$ and $0.089 / 0.152)$ of the levels in the control group at 9 and 11 months since arrival.

Table 2 The effect of the work-first policy on monthly work hours, monthly labor income, and average hourly wages per month, men

\begin{tabular}{|c|c|c|c|c|c|}
\hline & \multicolumn{5}{|c|}{ Months since arrival } \\
\hline & 7 & 9 & 11 & 13 & 15 \\
\hline 1. Work hours & $\begin{array}{l}1.329 \\
(2.735)\end{array}$ & $\begin{array}{l}10.39 * * * \\
(3.411)\end{array}$ & $\begin{array}{l}11.95 * * * \\
(4.054)\end{array}$ & $\begin{array}{l}9.153^{*} \\
(5.104)\end{array}$ & $\begin{array}{l}-2.181 \\
(6.078)\end{array}$ \\
\hline Control group mean & 7.6 & 12.5 & 17.4 & 22.7 & 27.5 \\
\hline$N$ & 4333 & 4333 & 4274 & 4072 & 3857 \\
\hline 2. Labor income (DKK) & $\begin{array}{l}200.8 \\
(379.9)\end{array}$ & $\begin{array}{l}1339.7 * * * \\
(483.2)\end{array}$ & $\begin{array}{l}1503.3^{* * * *} \\
(557.4)\end{array}$ & $\begin{array}{l}1396.0^{*} \\
(723.3)\end{array}$ & $\begin{array}{l}400.2 \\
(863.2)\end{array}$ \\
\hline Control group mean & 1032.2 & 1729.2 & 2313.5 & 3086.5 & 3731.4 \\
\hline$N$ & 4333 & 4333 & 4197 & 4072 & 3857 \\
\hline 3. Employed & $\begin{array}{l}0.010 \\
(0.022)\end{array}$ & $\begin{array}{l}0.051 * \\
(0.027)\end{array}$ & $\begin{array}{l}0.089 * * * \\
(0.030)\end{array}$ & $\begin{array}{l}0.065^{* *} \\
(0.033)\end{array}$ & $\begin{array}{l}0.016 \\
(0.035)\end{array}$ \\
\hline Control group mean & 0.067 & 0.111 & 0.152 & 0.199 & 0.240 \\
\hline$N$ & 4333 & 4333 & 4274 & 4072 & 3857 \\
\hline 4. Hourly wage (DKK) & $\begin{array}{l}20.10 \\
(24.81)\end{array}$ & $\begin{array}{l}-7.202 \\
(10.68)\end{array}$ & $\begin{array}{l}-2.199 \\
(12.87)\end{array}$ & $\begin{array}{l}8.871 \\
(7.402)\end{array}$ & $\begin{array}{l}43.64 * * * \\
(13.49)\end{array}$ \\
\hline Control group mean & 159.9 & 138.9 & 136.4 & 134.8 & 136.1 \\
\hline$N$ & 393 & 622 & 811 & 944 & 1013 \\
\hline
\end{tabular}

Each estimate is a separate OLS estimate of the treatment effect, $\beta_{s}$ in model (1), for different outcomes and at different points in time since arrival. The estimates in 4 . for the hourly wage are conditional on employment. The model includes the following control variables at time of arrival: indicators for living in a couple, having children, country of origin, residence permit type, municipality fixed effects, age fixed effects, and a quadratic function of calendar time. Standard errors in parentheses. * $p<0.1, * * p<0.05, * * * p<0.01$ 
Table 3 The effect of the work-first policy on transfer income and attrition, men

\begin{tabular}{llllll}
\hline \multicolumn{7}{l}{ Months since arrival } \\
\cline { 2 - 5 } & 7 & 9 & 11 & 13 & 15 \\
\hline 1. Welfare benefit receipt & 0.0226 & -0.0019 & -0.010 & -0.008 & -0.039 \\
& $(0.018)$ & $(0.024)$ & $(0.027)$ & $(0.033)$ & $(0.043)$ \\
2. Student grant receipt & -0.007 & 0.001 & $0.031 * * *$ & $0.041 * * *$ & $0.050^{* * *}$ \\
3. Attrition & $(0.006)$ & $(0.009)$ & $(0.010)$ & $(0.012)$ & $(0.015)$ \\
& -0.005 & -0.001 & -0.005 & -0.011 & 0.0001 \\
& $(0.006)$ & $(0.008)$ & $(0.010)$ & $(0.012)$ & $(0.017)$ \\
\hline
\end{tabular}

Separate monthly OLS estimates of effects from model (1), with the same control variables as in Table 2. The outcomes are dummies for welfare benefit receipt; student grant receipt in week 30, 39, 47, 56, and 65 since settlement; and attrition in the following month. Standard errors in parentheses. $* p<0.1, * * p<0.05$, *** $p<0.01$

The row labelled "4. Hourly wages" shows no effect on hourly wages for men who are working within the first year, but a positive effect 15 months since arrival. The results for hourly wages should be interpreted with care because the group who is working is a selected sample. If refugees react to the work-first policy by lowering their reservation wages and obtain employment earlier, this could be masked if it mainly takes place among higher ability refugees who would have waited longer to find a job in the absence of the policy. Indeed, I do find indications of such a positive selection into employment: The treated who find work at a given point in time are younger and are enrolled at a higher level of the Danish course than the controls who find a job at the same point in time since their arrival. There is on the other hand no indication that the work-first policy induces job search in new industries: The most common industries among employed refugees are similar for the treated and the controls after nine and 13 months since their arrival. The most common industries in which the refugees are working are the hospitality industry, property services (such as cleaning), and retail services.

Figure 3 shows how the model fits the observed means for work hours across monthly arrival cohorts. The figure shows that the model fits the data relatively well and clearly shows the common increase in work hours measured after 10 and 13 months for the treatment group arriving from October onwards, but that the same is not true after 7 months.

Table 3 collects estimates from model (1) with other outcomes. The first column contains results for welfare benefits receipt. It shows that, despite the increase in work hours, employment rates, and labor income, the probability of receiving welfare benefits does not change. Welfare benefits are means-tested, and the results suggest that the refugees who starts working because of the work-first policy are still eligible for welfare benefits, i.e., that they are only working as low paid for relatively few hours. The second column shows that the share who receives public student grants after 11 and 13 months increases by three to five percentage points for men. These are substantial relative effects and subsequent analyses show they are driven by single men without children, with some educational background from home. The student 


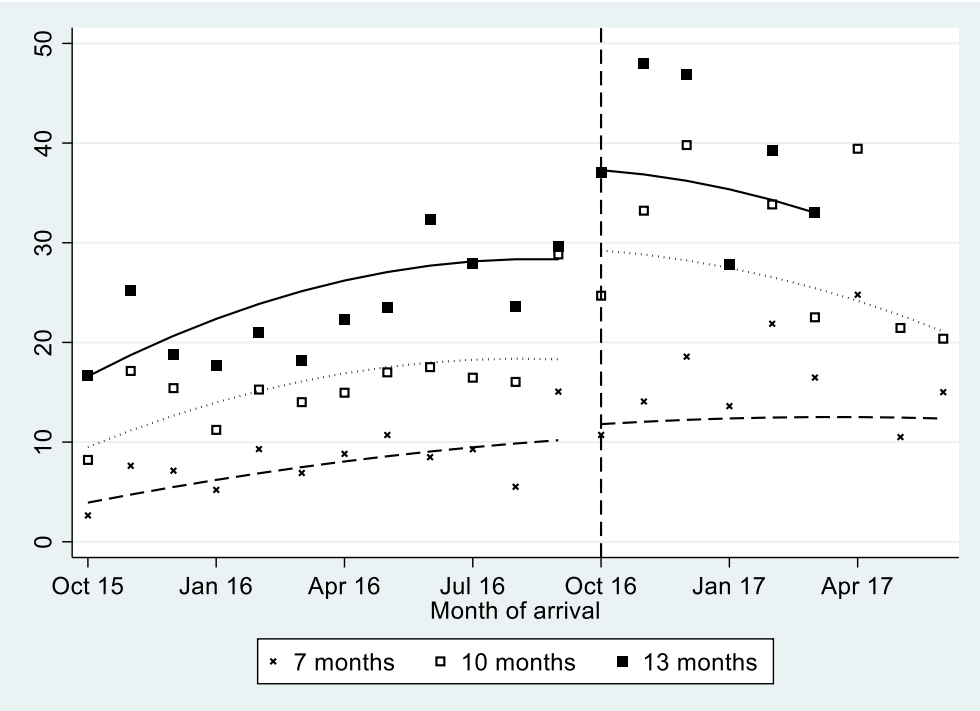

Fig. 3 Predicted and observed monthly work hours by arrival cohort, men. Observed means by arrival cohort and predicted means from model (1) using a squared calendar time specification

grant is available to all adults enrolled in post-secondary education in Denmark and is on par with the welfare benefit level for immigrants without children. The fourth column shows no effect on attrition (either due to death or emigration). In the next subsections, I consider the robustness of the results and explore effect heterogeneity and potential mechanisms.

\subsection{Robustness analyses}

This section addresses whether the results are sensitive with respect to how calendar time is controlled for. This is important since calendar time is a potential confounder in a before-after design. The results are shown in Table 4 for the main outcomes: work hours, labor income, and employment, measured 11 months since arrival (this is chosen because the effects peak at this point). Similar results are found for women in Appendix Table 9.

The result denoted as (1) in Table 4 shows the estimate without controlling for calendar time and shows that, even when controlling for individual characteristics, the treated cohorts have a higher number of work hours, a higher employment rate, and higher labor income than the control group. The estimate of the effects drops by $50 \%$ when controlling for a common linear calendar time trend in column (2). Column (3) includes the results from Table 2 with a quadratic specification of calendar time, and column (4) includes a cubic specification. In column (5), I examine the sensitivity to the common time effect assumption by including a linear trend that is allowed to differ for the treated and the controls (i.e., it is only a level shift that is attributed to the treatment). ${ }^{10}$ I call this a model with a group specific trend. It is seen that the latter

\footnotetext{
${ }^{10}$ Note that while this model allows for different time trends for the controls and the treated, which is relaxed in comparison to (1), it is still conditional on no differential response to the business cycle.
} 
Table 4 The effect of the work-first policy on monthly outcomes 11 months since arrival, robustness analysis for men

\begin{tabular}{|c|c|c|c|c|c|c|}
\hline & (1) & (2) & (3) & (4) & (5) & (6) \\
\hline 1. Work hours & $\begin{array}{l}12.92 * * * \\
(2.135)\end{array}$ & $\begin{array}{l}5.847 * \\
(3.264)\end{array}$ & $\begin{array}{l}11.95 * * * \\
(4.054)\end{array}$ & $\begin{array}{l}9.701 * * \\
(4.470)\end{array}$ & $\begin{array}{l}9.549 * * * \\
(3.575)\end{array}$ & $\begin{array}{l}13.62 * * * \\
(4.031)\end{array}$ \\
\hline RMSE & 47.47 & 47.43 & 47.40 & 47.40 & 47.40 & 50.04 \\
\hline Adj. $R^{2}$ & 0.120 & 0.121 & 0.123 & 0.123 & 0.123 & 0.0203 \\
\hline 2. Labor income (DKK) & $\begin{array}{l}1649.5^{* * *} \\
(293.5)\end{array}$ & $\begin{array}{l}735.2 \\
(448.7)\end{array}$ & $\begin{array}{l}1503.3 * * * \\
(557.4)\end{array}$ & $\begin{array}{l}1273.4 * * \\
(614.5)\end{array}$ & $\begin{array}{l}1173.3^{* *} \\
(491.6)\end{array}$ & $\begin{array}{l}1852.6^{* * *} \\
(567.4)\end{array}$ \\
\hline RMSE & 6525.3 & 6520.3 & 6516.9 & 6517.0 & 6517.4 & 7044.4 \\
\hline Adj. $\mathrm{R}^{2}$ & 0.135 & 0.136 & 0.137 & 0.137 & 0.137 & 0.0200 \\
\hline 3. Employed & $\begin{array}{l}0.0850 * * * \\
(0.0165)\end{array}$ & $\begin{array}{l}0.0404 \\
(0.0252)\end{array}$ & $\begin{array}{l}0.089 * * * \\
(0.030)\end{array}$ & $\begin{array}{l}0.0828 * * \\
(0.0345)\end{array}$ & $\begin{array}{l}0.0716^{* * *} \\
(0.0276)\end{array}$ & $\begin{array}{l}0.0977 * * * \\
(0.0306)\end{array}$ \\
\hline RMSE & 0.366 & 0.366 & 0.366 & 0.366 & 0.366 & 0.380 \\
\hline Adj. $R^{2}$ & 0.0959 & 0.0969 & 0.0984 & 0.0983 & 0.0983 & 0.0192 \\
\hline Individual controls & Yes & Yes & Yes & Yes & Yes & No \\
\hline Calendar time & No & Linear & Quad. & Cubic & Group trend & Quad. \\
\hline
\end{tabular}

Separate monthly OLS estimates of effects from model (1), with the same control variables as in Table 2. Calendar time is excluded in (1); included as a linear, quadratic, or cubic polynomial in (2)-(4); and a spline function in (5) with a separate linear trend for controls and treated. Calendar time is included as a quadratic polynomial in (6), but covariates are excluded. RMSE is the root-mean-squared error. Standard errors in parentheses. * $p<0.1$, ** $p<0.05$, *** $p<0.01$

three models produce almost identical results. At the same time, the latter three models have the largest adjusted R-squared and the lowest root-mean-squared error and are therefore the preferred specification based on statistical fit. The results therefore show some sensitivity to the specification of calendar time, as often is the case for beforeafter designs, but that the preferred specifications provide relatively stable positive and significant effect estimates. Finally, column (6) contains the results with the quadratic specification but without individual control variables. The results show that observed compositional changes only explain a small part of the effect of the policy: All estimates are inflated by $10-20 \%$ without individual controls. This suggests that the compositional changes observed in Table 1 are of minor importance. This may be explained by the fact that, compared to the overall variation in skill levels in the Danish labor market, the group of refugees is a relatively homogeneous group broadly characterized by low skills and lack of Danish language proficiency (at arrival). Nevertheless, below, I examine whether the results still hold within groups of given country of origin and language course level.

\subsection{Placebo tests}

To provide further evidence on the plausibility of the results, I conduct two different placebo analyses. In the first analysis, I estimate model (1) with an artificial treatment dummy that is rolled backwards in time. The results are shown in Fig. 4, where time zero corresponds to the actual treatment time, i.e., October 2016. In the light of 

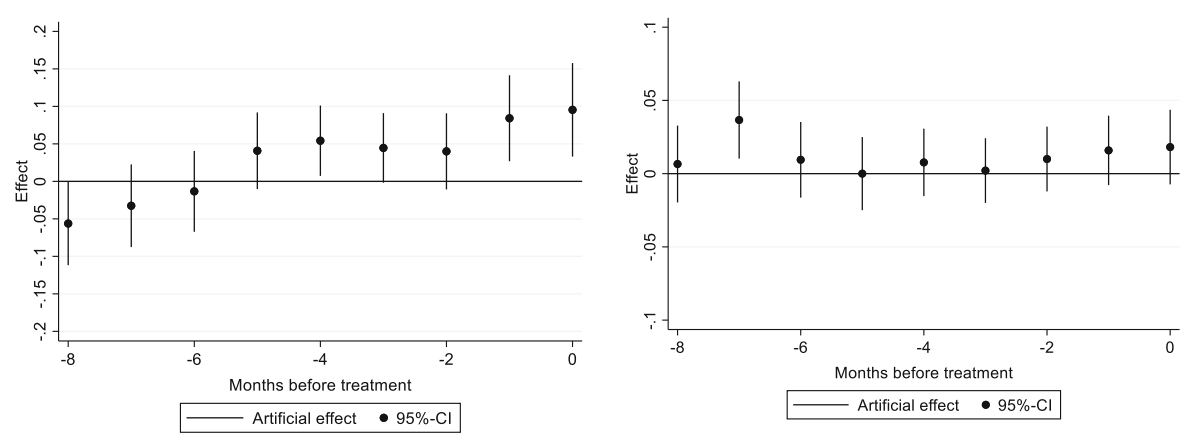

Notes: Estimates of the effects from model (1) with artificial treatments and control variables as in Table 2. The effect at zero on the first axis corresponds to the effect on employment from Table 2.

Fig. 4 Placebo effects on employment rate 12 months since arrival (men, women). The dots are estimates of the effect from model (1), and the same control variables as in Table 2. The effects are estimated with an artificial treatment and are presented with the artificial time of treatment at the horizontal axis. The vertical bars are $95 \%$ confidence intervals

continued improving labor market conditions that were shown for Danes in Fig. 1, I would expect the placebo effects to be continuously increasing over time if improving labor market conditions was the explanation for the estimated effects. The figure shows that the effect is largest at the true treatment date ( 0 in the figure) and the month before, and with one exception insignificant at earlier points in time. There is a tendency for an upward trend in the effects but only when moving the artificial treatment time from 8 to 5 months before the actual treatment, and the placebo effects are constant from then on and until one month before the actual policy is implemented. This period of time with the temporary upward trend in placebo estimates is around the time where the policy initiative was being debated and decided upon. The policy initiative received substantial public attention and it was a common viewpoint that refugees should enter the labor market at an earlier stage. ${ }^{11}$ It is therefore likely that the results reflect that a few municipalities are implementing work-first strategies targeting refugees in advance of the policy. Since it implies that the control group may be partly treated, it implies that the estimated effects may be downward biased.

In the second placebo analysis, I estimate model (1) in a $10 \%$ random sample of Danish welfare benefit recipients who are not affected by the policy. They are, on the other hand, affected by the changes in the business cycle and potentially by other policy interventions that occurred during the same period for all social assistance recipients. The model is estimated for Danes at given durations of welfare spells (corresponding to the time since arrival for refugees). Figure 5 shows that only six of the 38 estimates significant, and they are all negative. This result illustrates that the intuitive impression that effects are upward biased in the presence of improving labor market conditions needs not hold. If anything, the negative results suggest that the model may over control the business cycle, i.e., like the previous placebo analysis, that the effects may be downward biased.

\footnotetext{
${ }^{11}$ This viewpoint was for instance recommended by an Expert Committee that examined the entire Danish active labour market policy in 2015 (The Expert Committee on the Examination of the Active Labour Market Policy 2015: New roads towards Employment - For persons with Marginal Attachment to the Labour Market).
} 

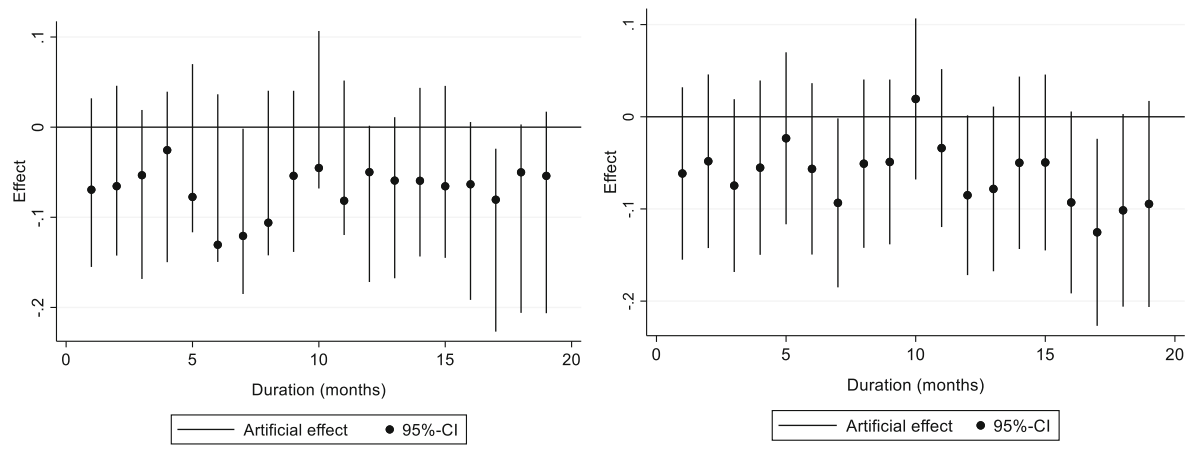

Notes: Estimates of the effects from model (1), with the control variables as in Table 2.

Fig. 5 Placebo effects on employment for a sample of Danish welfare recipients (men, women). The dots are estimates of the effects from model (1), with the same control variables as in Table 2. The effects are estimated for Danish welfare recipients at a given duration of time since the welfare spell has begun. The vertical bars are $95 \%$ confidence intervals

\subsection{Effect heterogeneity}

In this section, I present results from estimations of model (1) across subgroups to explore potential effect heterogeneity. The results are shown for the three main labor market outcomes hours worked, labor income, and employment, measured at 11 months since arrival in Table 5. The subgroups are whether the immigrant has arrived as a couple or not, arrived with a child or not, is from Syria or not, has received refugee status or not (in which case they are family reunified to a refugee), and the three levels of assigned Danish courses.

All within-group estimated effects are positive for men, most are significantly different from zero, and there are no significant differences across subgroups. Albeit insignificant, there are some relatively large differences in the effect of the work-first policy for men across different types of households. The largest effects on work hours and labor earnings are found between refugees enrolling in the lowest and the highest level of the Danish course, where the effect for the latter group is more than twice the size than for the former. Since the Danish course level is a proxy for previous education level, this result indicates that the effect of the work-first policy on work hours and labor earnings is larger for refugees with higher skills, although keeping in mind that differences are insignificant. In contrast, looking at employment rates, the effects are larger for single men, men with no children, men not from Syria, and men in the intermediate language course level. These differences - although still keeping mind they are insignificant - tentatively suggest that the work-first policy induces some lowskilled to react on the extensive labor supply margin, whereas some men with higher skills react by working more hours (the intensive margin). I also note that even though there are differences between the estimates for Syrians and non-Syrians, the effects are significant and large for both groups. The results therefore also indicate that different characteristics in the treatment group and control group observed in Table 1 do not explain the effects.

I also show that the work-first policy has no or small effects for women across most of these subgroups (cf. Appendix Table 10). The absence of effects for single women and women without children indicates that the effects are not smaller for women 


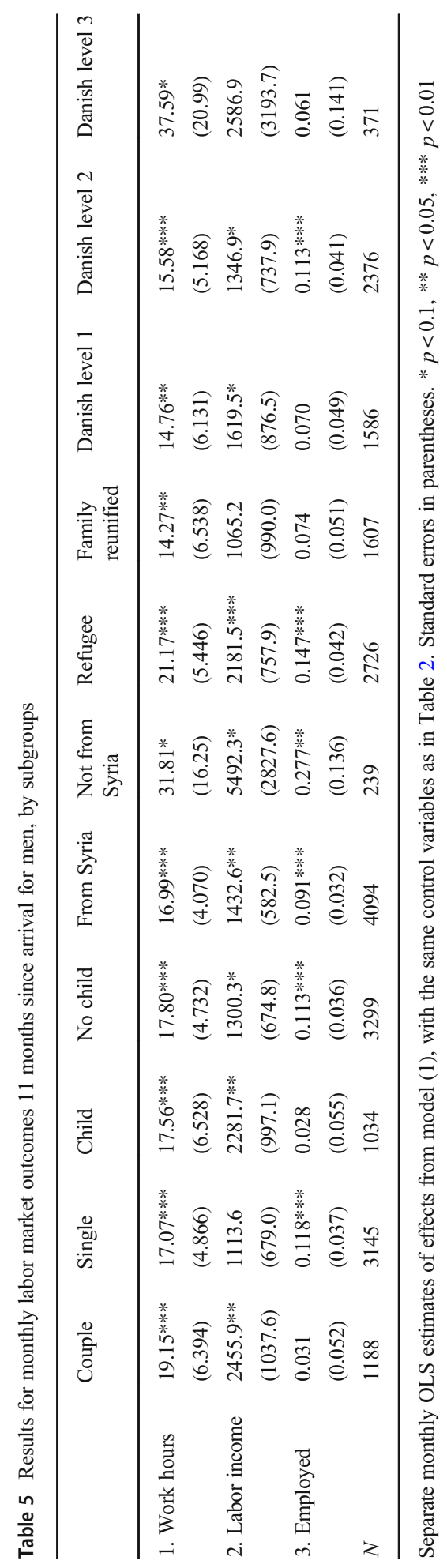


because they stay at home due to household and childcare responsibilities. Two alternative explanations for the smaller effects for women are that they are less educated or that the work-first policy is implemented differently for women than for men. Table 1 showed no indication of large differences in skill level between men and women, when proxied by the level of the Danish course. I explore the second explanation in the next section.

\subsection{Mechanisms: characterizing treatment}

I have shown that the work-first policy has an employment effect for men, but that the effect is absent or much smaller for women. These are intent-to-treat effects and I therefore look at the effect of the work-first policy on the two elements in the work-first policy that is supposed to be driving the effect: The job readiness assessment and participation in on-the-job training. I also look at whether the policy induces changes in participation in two other types of support in the introduction program: classroom training (mainly consisting of the language course) and other labor market programs (e.g., counselling and job search courses). These analyses show whether the work-first policy is implemented as intended, and whether differences in implementation can explain the more limited effects for women. Figure 6 shows the raw share assessed as job ready in the first two weeks since arrival: It rises from 4 to $8 \%$ for those arriving in before October 2016 to $30-40 \%$ for men and 20-30\% for women arriving from October 2016. As time goes by and individuals are reassessed as job ready or not, the rates rise to $70-80 \%$.

Table 6 contains estimates from model (1) of the effect of the work-first policy on the number of cumulated weeks of participation in each of the three different types of support in the introduction program and on weeks assessed as job ready. The results show that the work-first policy also has a positive impact on the share that is declared job ready when controlling for background characteristics and time trends. The effect peaks after 26 weeks for men, where the work-first policy has raised the number of weeks assessed as job ready by 5.5 weeks and a similar effect is reached after 39 weeks for women. The work-first policy also has a positive impact on the number of weeks that the treatment group participates in on-the-job training, but the effect is more
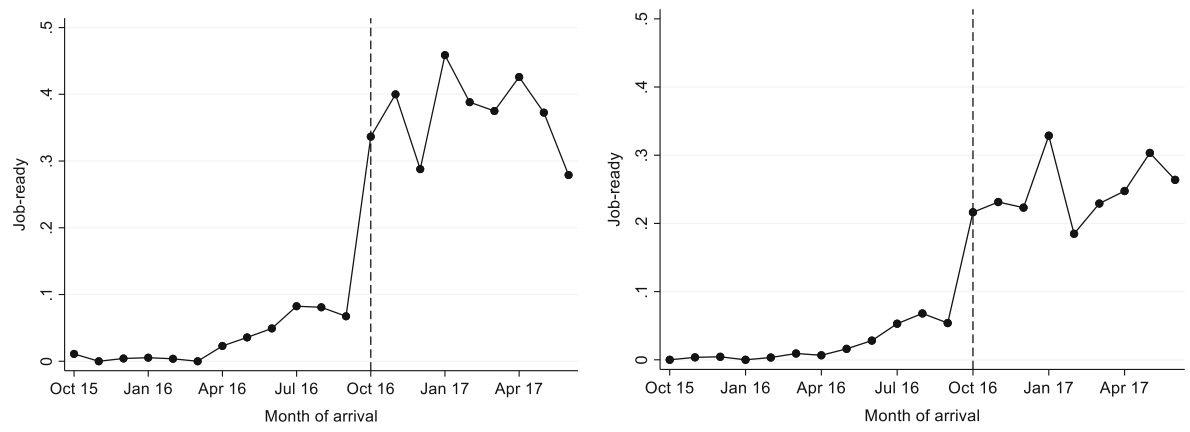

Note: The share assessed as job-ready 2 weeks since arrival

Fig. 6 Observed share declared job ready upon arrival by arrival cohort (men, women). The share of refugees who are assessed as job ready two weeks since arrival, by week of arrival 
Table 6 Effects of the work-first policy on cumulative weeks of participation in the integration program

\begin{tabular}{|c|c|c|c|c|c|}
\hline & \multicolumn{5}{|c|}{ Weeks since arrival: } \\
\hline & 8 & 13 & 26 & 39 & 52 \\
\hline \multicolumn{6}{|l|}{ Men: } \\
\hline 1. Job ready & $\begin{array}{l}1.920 * * * \\
(0.131)\end{array}$ & $\begin{array}{l}3.611 * * * \\
(0.233)\end{array}$ & $\begin{array}{l}5.461 * * * \\
(0.510)\end{array}$ & $\begin{array}{l}4.980 * * * \\
(0.765)\end{array}$ & $\begin{array}{l}3.710 * * * \\
(1.013)\end{array}$ \\
\hline 2. Job training & $\begin{array}{l}0.152 * \\
(0.0850)\end{array}$ & $\begin{array}{l}0.449 * * \\
(0.184)\end{array}$ & $\begin{array}{l}0.728 \\
(0.459)\end{array}$ & $\begin{array}{l}1.196 * \\
(0.709)\end{array}$ & $\begin{array}{l}1.953 * * \\
(0.931)\end{array}$ \\
\hline 3. Classroom training & $\begin{array}{l}0.417 * * \\
(0.178)\end{array}$ & $\begin{array}{l}0.134 \\
(0.283)\end{array}$ & $\begin{array}{l}-0.429 \\
(0.554)\end{array}$ & $\begin{array}{l}-0.945 \\
(0.809)\end{array}$ & $\begin{array}{l}-2.020^{*} \\
(1.046)\end{array}$ \\
\hline 4. Other labor market programs & $\begin{array}{l}-0.228^{* *} \\
(0.114)\end{array}$ & $\begin{array}{l}-0.087 \\
(0.178)\end{array}$ & $\begin{array}{l}0.121 \\
(0.343)\end{array}$ & $\begin{array}{l}0.358 \\
(0.511)\end{array}$ & $\begin{array}{l}0.436 \\
(0.645)\end{array}$ \\
\hline$N$ & 4332 & 4331 & 4307 & 4292 & 4261 \\
\hline \multicolumn{6}{|l|}{ Women: } \\
\hline 1. Job ready & $\begin{array}{l}1.421 * * * \\
(0.118)\end{array}$ & $\begin{array}{l}2.771 * * * \\
(0.211)\end{array}$ & $\begin{array}{l}5.097 * * * \\
(0.450)\end{array}$ & $\begin{array}{l}5.582 * * * \\
(0.692)\end{array}$ & $\begin{array}{l}5.423 * * * \\
(0.929)\end{array}$ \\
\hline 2. Job training & $\begin{array}{l}0.0922^{* *} \\
(0.039)\end{array}$ & $\begin{array}{l}0.172 * \\
(0.098)\end{array}$ & $\begin{array}{l}0.190 \\
(0.279)\end{array}$ & $\begin{array}{l}-0.192 \\
(0.459)\end{array}$ & $\begin{array}{l}0.170 \\
(0.626)\end{array}$ \\
\hline 3. Classroom training & $\begin{array}{l}0.257 * * \\
(0.122)\end{array}$ & $\begin{array}{l}0.315 \\
(0.227)\end{array}$ & $\begin{array}{l}0.786^{*} \\
(0.473)\end{array}$ & $\begin{array}{l}1.644 * * \\
(0.727)\end{array}$ & $\begin{array}{l}1.341 \\
(0.941)\end{array}$ \\
\hline 4. Other labor market programs & $\begin{array}{l}-0.165^{* *} \\
(0.078)\end{array}$ & $\begin{array}{l}-0.0793 \\
(0.129)\end{array}$ & $\begin{array}{l}0.153 \\
(0.258)\end{array}$ & $\begin{array}{l}0.386 \\
(0.375)\end{array}$ & $\begin{array}{l}0.584 \\
(0.471)\end{array}$ \\
\hline$N$ & 4538 & 4537 & 4525 & 4502 & 4473 \\
\hline
\end{tabular}

Separate monthly OLS estimates of effects from model (1), with the same control variables as in Table 2. The outcomes are indicator variables that takes value one if the refugee participates in a given activity within the integratactivation program in given weeks since arrival, and are zero otherwise. Standard errors in parentheses. $* p<0.1, * * p<0.05, * * * p<0.01$

limited: After one year, men have participated in job training for 2 more weeks, whereas this effect never increases beyond 0.2 week (i.e., one day) for women. The results therefore suggest that different participation rates in job training may be part of the explanation for the different effects of the work-first initiative for men and women.

There could be various reasons for a differential treatment of men and women: Since job training requires a match between the unemployed and an employer, it could occur due to differential selection of industries for men and women, or from discrimination (or imperfect information) from employers against women. Differential treatment of men and women could also arise if caseworkers treat women more lenient. The latter might occur because the women are more reluctant to participate in the labor market, e.g., because they have no experience from their home country or because they have larger household responsibilities.

The next set of results (in rows 3 and 4) explore the effect of the policy on other parts of the introduction program: They show that there is a negative effect of the work-first policy on participation in classroom training for men. The effects are of a similar size as the effect on on-the-job training. This indicates that participation in on-the-job training 
(or employment) crowds out the use of this part of the introduction program for men. Although a partial crowd-out could be expected due to a new option to postpone language courses, a full crowd-out was not the main intention with the policy. For women, participation in classroom training increases by more than a week in the first year after arrival. There is only a small and temporary effect on participation in other labor market programs.

\section{Discussion}

The large influx of asylum seekers in Western Europe in 2015 led to substantial fiscal costs for national governments. This in turn resulted in a demand for effective solutions that could help refugees become self-reliant. Many countries are considering, or already implementing, work-first policies to expedite immigrants' entry into the labor market. Recent studies on early employment bans and the timing of job entry suggest that such approaches might be effective in the long run (Marbach et al. 2018; Aaslund et al. 2017). This approach stands in contrast to a long tradition that has emphasized human capital investments, primarily in the form of language training to immigrants. Examples of the human capital investment approach are the Danish introduction program from 1999, and German and Dutch legislation introduced in 2005 and 2007, that emphasized language proficiency as an integral part of immigrant integration. The current study estimates the effect of a work-first policy as an addendum to such a human capital strategy.

I use the introduction of a Danish work-first policy in 2016 as a quasi-experiment to estimate its effect on employment for refugees. The current study therefore addresses the challenge of integrating the recent inflow of refugees in Europe but is naturally limited to the study of the short-term effects of the policy.

I show that the work-first policy has a relatively large and positive effect on the share of men who find a job within the first year after arrival. The effect emerges after $8-$ 10 months in the country, which corresponds to the time used to participate in two to three spells of on-the-job training, which is an integral part of the policy. The effect levels out on around 10 percentage points more men who have been employed at some point one year since arrival onwards. The employment effect also shows up in the number of hours worked and labor income, but these effects are more modest and vanish after 15 months. In addition, there are no effects on welfare benefit receipt. The results jointly suggest that the work-first policy induces more men to find employment, and that they do so faster, but that they work for few hours and/or are employed for short periods of time. In contrast, the work-first policy has no employment effects for women.

The positive employment effect for men is robust: The effect is found across different groups of refugees, including both Syrians, where a majority arrive before the policy, and non-Syrians, where a majority arrive after the policy. The estimated effects are also robust towards different ways of controlling for the business cycle, and I find no substantial effect in two types of placebo analyses. If anything, the placebo analyses both suggest that the estimated effect is downward biased. Nevertheless, I next discuss three separate explanations for why the results could still be biased.

First of all, it cannot be ruled out that early arriving cohorts differ from later arriving cohorts on unobserved characteristics. I have aimed at limiting this potential source of bias by accounting for observed differences in demographics, country of origin and 
skill level at arrival, and by focusing on cohorts that arrived in Denmark within a relatively narrow period of time of one and a half year. If unobserved skills should explain the positive effect, it should be the case that the least skilled should arrive first. While I am not aware of any empirical evidence on within-country, cross-time selfselection of refugees, my prior would be the opposite: That the more able with better resources and connections would flee first. Since a majority of the sample are from Syria, it is interesting to further discuss a potential bias arising from selection in their migration patterns. The waiting time in the Danish asylum system at the time of consideration (2015-16) is below one year (Hvidtfeldt and Schultz-Nielsen 2017), so Syrians are fleeing after the escalation of the Syrian conflict in 2011-13 and during the turmoil of the US and Russian intervention of 2014-16. ${ }^{12}$ The specific case of the Syrian refugees therefore supports that those who arrive later are likely to be those with less means to flee early and those who may have suffered more from experiencing longer periods of the war. It therefore seems most likely that if a bias from selective timing of migration is present, this too would produce a downward bias (as did the placebo analyses).

A second potential reason for a bias in the presented results is that the increased focus on refugees that occurred in early 2016 has increased the demand for employing refugees. If such an effect operates independently of the work-first initiative, it seems most likely that employers would hire refugees who have stayed for some time and already learned some customs and language, as opposed to newly arrived refugees. This, again, favors the control group over the treatment group and would also produce a downward bias.

A third potential reason for a bias in the presented results is that refugees who arrive after October 2016 are waiting longer for asylum and therefore have more time for investment in host-specific capital while waiting. Although the waiting time did rise slightly from 2015 to the first half of 2016 (I have no statistics after that), it was still below a year. Moreover, it is by no means obvious that a longer period of waiting for asylum is merely good. A recent Danish study finds that a longer waiting time for asylum does not affect labor market integration once granted asylum (Hvidtfeldt et al. 2018), but this is an area where further research is needed.

As is always the case, the estimated effects depend on specific circumstances under which the policy is implemented. In particular, the policy is implemented during an economic upturn and within a welfare regime that combines work requirements and reduced welfare benefits to raise the economic incentives for employment. Whether similar effects can be obtained under different circumstances is not known.

Having discussed potential biases and limitations, I turn attention to more specific results on gender differences and potential long-term effects. Previous studies have also found that labor market policies may affect male and female refugees differently, as I do here, but the previous results are too divergent to suggest a general pattern and few have examined possible explanations. ${ }^{13}$ The current study shows that a lower participation

\footnotetext{
${ }^{12}$ See, e.g., https://www.unhcr.org/ph/13427-seven-years-timeline-syria-crisis.html for a timeline of the Syrian conflict.

${ }^{13}$ Whereas several studies have found that active labor market policies have smaller effects for refugee women than refugee men (Heinesen et al. 2013; Røed and Raaum 2006; Rosholm and Vejlin 2010; Arendt 2020), there are exceptions (Lopalo 2019). A few studies suggest that skill investments (language and formal education) may benefit immigrant women more than immigrant men (Kennerberg and Aaslund 2010; Arendt 2018), but here, Lochmann et al. (2019) finds the opposite.
} 
rate in job training may partly explain the smaller effectsfor women. A related finding has been reported by Kennerberg and Aaslund (2010), who find that only women who completes language training in the Swedish introduction program benefit from it, but that drop-out rates are large. In contrast, the current study shows no indications that a difference in skill levels nor household and childcare responsibilities contribute to the smaller effects for women, but further research is needed to confirm this.

The fact that the work-first policy induces more men to find work quickly after their arrival is encouraging, but the fact that it fails to reduce the use of welfare benefits is disturbing. Still, early entry could provide a stepping-stone towards a more stable position on the labor market. There is, however, no indication that the type of job they find produces better long-term prospects than before the work-first policy: Even though more men are working, they are working few hours, and they find jobs at the same hourly wage and in the same industries as the non-treated. This is likely because the group is already entering the lowest paid jobs in specific industries with a large share of unskilled labor. The work-first policy may have an indirect impact on the quality of jobs held in the longer run because it affects skills investment: On the one hand, I find that the work-first policy reduces participation in language training for both men and women, but I cannot distinguish whether this is a permanent reduction or merely a delay. To the extent that language training is effective in the longer run, a permanent reduction will of course be important for the long-term consequences. On the other hand, the work-first policy also had a positive effect on the share of men who enrolled in education, so it also induces a shift towards other types of human capital investments. The expected long-run effects are therefore ambiguous.

In summary, the current study shows that an adjustment to the Danish introduction program succeeded in expediting entry to the labor market for male refugees, which is a policy objective in many Western countries. The study also raises points of concern: First, men find precarious jobs with few hours of work and reduce participation in language training. More efforts should therefore probably be made to avoid that early labor market entry reduces skills investment. And second, the smaller effectsfor women are discouraging, but the study suggests that raising low participation rates may be a fruitful avenue.

Acknowledgments Funding from the Rockwool Foundation is greatly appreciated. The study has benefited greatly from comments from participants at the seminar series at the Rockwool Foundation's Research Unit, at the Rockwool Foundations labor market conference in 2019, at the workshop "Forced Displacement, Asylum Seekers and Refugees" in London, the "EARN workshop on Integration" in Copenhagen, the ESPE conference in Bath, CReAM's Labor Workshop in Monferrato, and at the EALE conference in Uppsala. I am grateful for comments from Helena Skyt Nielsen, and Hyejin $\mathrm{Ku}$ and particularly for the very constructive comments from four reviewers and the editor, Klaus F. Zimmermann. I am solely responsible for the content of this paper and all potential errors are mine.

Funding This project was funded by the Rockwool Foundation, project grant 1191 .

Data availability Yes, from Statistics Denmark: https://www.dst.dk/en/TilSalg/Forskningsservice.

\section{Compliance with ethical standards}

Conflict of interest The author declares that he has no conflict of interest. 
Code availability Stata code available upon request.

\section{Appendix}

Table 7 The effect of the work-first policy on monthly work hours, labor income, and average hourly wages per month, women

\begin{tabular}{|c|c|c|c|c|c|}
\hline & \multicolumn{5}{|c|}{ Months since arrival } \\
\hline & 7 & 9 & 11 & 13 & 15 \\
\hline \multirow[t]{2}{*}{ 1. Work hours } & 0.963 & 0.635 & 1.988 & 1.698 & 1.090 \\
\hline & $(0.860)$ & $(1.172)$ & $(1.445)$ & $(1.711)$ & $(2.258)$ \\
\hline Baseline & 0.940 & 1.8 & 2.345 & 2.805 & 4.5 \\
\hline$N$ & 4538 & 4538 & 4448 & 4219 & 3979 \\
\hline \multirow[t]{2}{*}{ 2. Labor income (DKK) } & 154.8 & 115.1 & 245.2 & 244.4 & 256.1 \\
\hline & (124.8) & (159.6) & (183.6) & (217.6) & $(276.2)$ \\
\hline Baseline & 119.4 & 240.0 & 293.5 & 350.7 & 539.8 \\
\hline$N$ & 4538 & 4538 & 4448 & 4219 & 3979 \\
\hline \multirow[t]{2}{*}{ 3. Hourly wage (DKK) } & NA & 4.567 & -47.51 & -106.8 & 102.8 \\
\hline & & $(218.5)$ & $(42.86)$ & $(174.6)$ & (101.1) \\
\hline Baseline & 159.8 & 198.1 & 163.6 & 160.4 & 134.5 \\
\hline$N$ & 66 & 116 & 155 & 177 & 218 \\
\hline \multirow[t]{2}{*}{ 4. Employed } & 0.010 & 0.005 & 0.016 & 0.005 & 0.008 \\
\hline & $(0.008)$ & $(0.010)$ & $(0.012)$ & $(0.013)$ & $(0.016)$ \\
\hline Baseline & 0.010 & 0.021 & 0.026 & 0.034 & 0.048 \\
\hline$N$ & 4538 & 4538 & 4448 & 4219 & 3979 \\
\hline
\end{tabular}

Separate monthly OLS estimates of effects from model (1), with the same control variables as in Table 2 . See also notes to Table 2. Standard errors in parentheses. $* p<0.1$, ** $p<0.05$, *** $p<0.01$

Table 8 The effect of the work-first policy on transfer income and attrition, women

\begin{tabular}{llllll}
\hline \multicolumn{5}{l}{ Months since arrival } \\
\cline { 2 - 5 } & 7 & 9 & 11 & 13 & 15 \\
\hline 1. Welfare benefit receipt & 0.009 & 0.001 & 0.009 & 0.020 & 0.017 \\
& $(0.016)$ & $(0.018)$ & $(0.021)$ & $(0.024)$ & $(0.030)$ \\
2. Student grant receipt & -0.004 & -0.001 & 0.007 & -0.002 & -0.002 \\
3. Attrition & $(0.004)$ & $(0.005)$ & $(0.006)$ & $(0.010)$ & $(0.010)$ \\
& 0.005 & 0.008 & 0.005 & 0.003 & 0.005 \\
& $(0.004)$ & $(0.006)$ & $(0.008)$ & $(0.010)$ & $(0.013)$ \\
\hline
\end{tabular}

Separate OLS estimates of effects from model (1), with the same control variables as in Table 2. See also notes for Table 3. Standard errors in parentheses. * $p<0.1$, ** $p<0.05$, *** $p<0.01$ 
Table 9 The effect of the work-first policy on monthly outcomes 11 months since arrival, robustness analysis for women

\begin{tabular}{lllllll}
\hline & $(1)$ & $(2)$ & $(3)$ & $(4)$ & $(5)$ & $(6)$ \\
\hline 1. Work hours & $2.400^{* * *}$ & 1.708 & 1.988 & 1.751 & 1.922 & $2.421^{*}$ \\
& $(0.746)$ & $(1.222)$ & $(1.445)$ & $(1.595)$ & $(1.309)$ & $(1.388)$ \\
RMSE & 20.02 & 20.02 & 20.02 & 20.02 & 20.02 & 20.56 \\
Adj. R & 0.0731 & 0.0730 & 0.0728 & 0.0726 & 0.0728 & 0.00555 \\
2. Labor income (DKK) & $198.5 * *$ & 201.6 & 245.2 & 271.3 & 219.2 & $304.9 *$ \\
& $(94.76)$ & $(155.3)$ & $(183.6)$ & $(202.6)$ & $(166.3)$ & $(182.2)$ \\
RMSE & 2542.7 & 2543.0 & 2543.2 & 2543.5 & 2543.3 & 2697.3 \\
Adj. R & & & & & \\
3. Employed & 0.0869 & 0.0867 & 0.0866 & 0.0864 & 0.0865 & 0.0041 \\
& $0.0197 * * *$ & 0.0099 & 0.0155 & 0.0147 & 0.0134 & 0.0161 \\
RMSE & $(0.0065)$ & $(0.0108)$ & $(0.0128)$ & $(0.0141)$ & $(0.0116)$ & $(0.0122)$ \\
Adj. R ${ }^{2}$ & 0.177 & 0.177 & 0.177 & 0.177 & 0.177 & 0.181 \\
Individual controls & 0.0638 & 0.0639 & 0.0638 & 0.0636 & 0.0638 & 0.0047 \\
Calendar time & Yes & Yes & Yes & Yes & Yes & No \\
\hline
\end{tabular}

Separate monthly OLS estimates of the effects from model (1), with the same control variables as in Table 2. See also notes for Table 4. Standard errors in parentheses. $* p<0.1, * * p<0.05, * * * p<0.01$ 


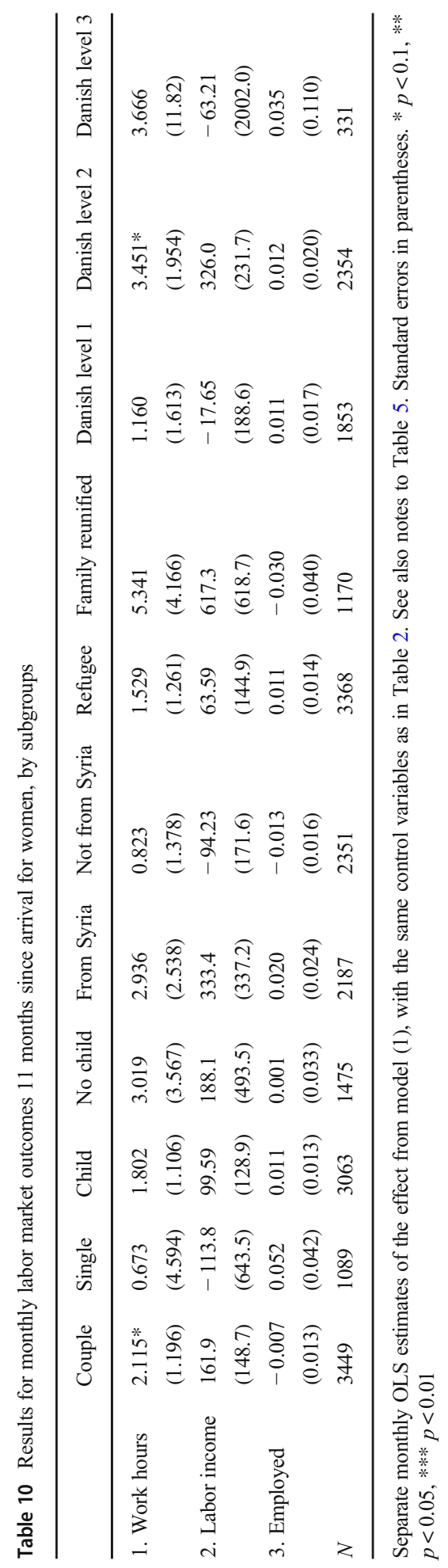


Open Access This article is licensed under a Creative Commons Attribution 4.0 International License, which permits use, sharing, adaptation, distribution and reproduction in any medium or format, as long as you give appropriate credit to the original author(s) and the source, provide a link to the Creative Commons licence, and indicate if changes were made. The images or other third party material in this article are included in the article's Creative Commons licence, unless indicated otherwise in a credit line to the material. If material is not included in the article's Creative Commons licence and your intended use is not permitted by statutory regulation or exceeds the permitted use, you will need to obtain permission directly from the copyright holder. To view a copy of this licence, visit http://creativecommons.org/licenses/by/4.0/.

\section{References}

Aaslund O, Johansson P (2011) Virtues of SIN: can intensified public efforts help disadvantaged immigrants? Eval Rev 35(4):399-427

Aaslund O, Forslund A, Liljeberg L (2017) Labour market entry of non-labour migrants - Swedish evidence. Ch. 4 in Bratsberg et al. (Eds.): Nordic Economic Policy Review 2017:520

Act No. 474 of 01/07/1998 on the integration of foreigners in Denmark. The Ministry of Interior

Andersen LH, Dustmann C, Landersø R (2019) Lowering welfare benefits: intended and unintended consequences for migrants and their families. Study paper 138. The ROCKWOOL Foundation Research Unit, Copenhagen

Ansala L, Aaslund O, Sarvimäki M (2018). Immigration history, entry jobs, and the labor market integration of immigrants. IFAU Working Paper 2018:20.

Arendt JN (2018) Sammenhængen mellem beskæftigelse og uddannelse for ikke-vestlige flygtninge og familiesammenførte (The relationship between employment and education for non-western refugees and family reunified immigrants). Working Paper 54, Copenhagen: The ROCKWOOL Foundation Research Unit

Arendt JN (2020) The effect of welfare benefit reductions on the integration of refugees. Study Paper No. 151. The ROCKWOOL Foundation Research Unit

Arendt JN, Bolvig I, Foged M, Hasager L, Peri G (2020) Integrating refugees: language training or work-first incentives? NBER Working Paper No. 26834

Bakker L, Dagevos J, Engversen G (2017) Explaining the refugee gap: a longitudinal study on labour market participation of refugees in the Netherlands. J Ethn Migr Stud 43(11):1775-1791

Bell B (2016) Crime and immigration. Do poor labor market opportunities lead to migrant crime? IZA World Labor 33(2):1-10

Bevelander P (2016) Integrating refugees into labor markets. IZA World of Labor 269. https://doi.org/10. 15185/izawol.269

Bolvig I, Arendt JN (2018) Nationale ramme for integrationsindsatsen af flygtninge, 1997-2017. VIVE, København

Bratsberg B, Raaum O, Røed K (2017) Immigrant labor market integration across admission classes. Ch. 1 in Bratsberg et al. (Eds.): Nordic Economic Policy Review 2017:520

Card D, Kluve J, Weber A (2018) What works? A meta-analysis of recent active labour market program evaluations. J Eur Econ Assoc 16(3):894-931

Chin A, Cortes KE (2015) The refugee/asylum seeker, Ch, 12 in Chiswick, B. and P. Miller (Eds.), Handbook on the Economics of International Immigration, Volume 1A, Elsevier Science

Chiswick BR, Miller PW (2014) International migration and the economics of language. IZA Discussion Papers, No. 7880

Clausen J, Heinesen E, Hummelgaard H, Husted L, Rosholm M (2009) The effect of integration policies on the time until regular employment of newly arrived immigrants: evidence from Denmark. Labour Econ 16(4):409-417

Consolidated Act No. 665 of 08/06/2016 on Amendments to the Act on Integration of foreigners in Denmark. The Ministry of Transport, Construction and Housing

Consolidated Act No.772 of 10/06/2015 of the Act on Danish Education for adult foreigners and others. The Ministry of Education

Constant AF, Zimmermann KF (2016) Towards a new European refugee policy that works. CESifo DICE report $4 / 2016$ 
Damm AP (2009) Ethnic enclaves and immigrant labor market outcomes: quasi-experimental evidence. J Labor Econ 27(2):281-314

Danzer AM (2011) Economic benefits of facilitating the integration of immigrants CESifo DICE Report $4 / 2011$

Desidero MV (2016) Integrating refugees into host country labor markets. Challenges and opportunities. Migration Policy Institute, Washington DC

Dustmann C, Fasani F, Frattini T, Minale L, Schoenberg U (2017) On the economics and politics of refugee migration. Econ Policy 32(91):497-550

Edin P-A, Fredriksson P, Aaslund O (2003) Ethnic enclaves and the economic success of immigrantsevidence from a natural experiment. Q J Econ 118(1):329-357

Fasani F, Frattini T, Minale L (2017) (The Struggle for) Refugee integration into the labour market: evidence from Europe. CReAM working paper 16/2017

Freedman S, Knab JT, Gennetian LA, Navarro D (2000) The Los Angeles jobs-first GAIN evaluation: final report on a work first program in a major urban center. Manpower Demonstration Research Corporation

Garibay MG, De Cyuper P (2013) The evaluation of integration policies across the OECD: a review. Policy Research Centre on Integration

Hayfron JE (2001) Language training, language proficiency and earnings of immigrants in Norway. Appl Econ 33(15):1971-1979

Heinesen E, Husted L, Rosholm M (2013) The effects of active labour market policies for immigrants receiving social assistance in Denmark. IZA J Migr 2(15):1-22

Hotz VJ, Imbens GW, Klerman JA (2006) Evaluating the differential effects of alternative welfare-to-work training components: a reanalysis of the California GAIN program. J Labor Econ 24(3):521-566

Hvidtfeldt C, Schultz-Nielsen ML (2017) Flygtninge og asylansøgere i Danmark 1997-2016. Arbejdspapir no. 50. ROCKWOOL Fondens Forskningsenhed, København

Hvidtfeldt C, Schultz-Nielsen ML, Tekin E, Fosgerau M (2018) An estimate of the effect of waiting time in the Danish Asylum system on post-resettlement employment among refugees: separating the pure delay effect from the effects of the conditions under which refugees are waiting. PLoS One 13(11):e0206737. https://doi.org/10.1371/journal.pone.0206737

Hynie M (2018) The societal determinants of refugee mental health in the post-migration context: a critical review. Can J Psychiatry 63(5):297-393

Joona PA, Nekby L (2012) Intensive coaching of new immigrants: an evaluation based on random program assignment. Scand J Econ 114(2):575-600

Joona PA, Lanninger AW, Sundström M (2016) Reforming the integration of refugees: the Swedish experience. IZA Working Paper No. 10307. IZA, Bonn

Kennerberg L, Aaslund O (2010) Sfi och arbetsmarknaden (Swedish for immigrants and the labour market). IFAU Working paper 2010: 10

Konle-Seidl R, Bolitz G (2016) Labor market integration of refugees: strategies and good practices. EMP Study 2016-08. Policy Department A: Economic and Scientific Policy, the European Parliament

Laurentsyeva N, Venturini A (2017) The social integration of immigrants and the role of policy-a literature review. Intereconomics 5:282-292

Liebig T, Tronstad K (2018) Triple disadvantage?: a first overview of the integration of refugee women. OECD Social, Employment and Migration Working Papers, No. 216. OECD Publishing, Paris

Lochmann A, Rapoport H, Speciale B (2019) The effect of language training on immigrants' economic integration: empirical evidence from France. Eur Econ Rev 113:265-296

LoPalo M (2019) The effects of cash assistance on refugee outcomes. J Public Econ 170:27-52

Marbach M, Hainmueller J, Hangartner D (2018) The long-term impact of employment bans on the economic integration of refugees. Sci Adv 4(9):1-6. https://doi.org/10.1126/sciadv.aap9519

Martín I, Arcarons A, Aumüller J, Bevelander P, Emilsson H et al. (2016) From refugees to workers mapping labour-market integration support measures for asylum seekers and refugees in EU member. Volume II: Literature review and country case studies. Bertelsmann Stiftung

Orlov G (2017) The impact of language training on the transfer of pre-immigration skills and the wages of immigrants. Working Paper

Porter M, Haslam N (2005) Predisplacement and postdisplacement factors associated with mental health of refugees and internally displaced persons: a meta-analysis. J Am Med Assoc 294(5):602-612

Rigsrevisionen (2018) Beretning om Forløbet for Flygtninge med Traumer (examination of pathways for refugees with trauma). Copenhagen

Røed K, Raaum O (2006) Do labour market programmes speed up the return to work? Oxf Bull Econ Stat 68(5):541-568 
Rosholm M, Vejlin R (2010) Reducing income transfers to refugee immigrants: does start-help help you start? Labour Econ 17(1):258-275

Sarvimäki M, Hämäläinen K (2016) Integrating immigrants: the impact of restructuring active labor market programs. J Labor Econ 34(2):479-508

Schultz-Nielsen M (2017) 2. Labour market integration of refugees in Denmark. Ch. 2. In Bratsberg et al. (eds) Nordic Economic Policy Review. TemaNord 2017: p 520

Wike R, Stokes B, Simmons K (2016) Europeans fear wave of refugees will mean more terrorism, Fewer Jobs. Pew Research Center

Zimmerman KF (2017) Refugee and migrant labor market integration: Europe in need of a new policy agenda. In: Bauböck R and Tripkovic M (eds) The integration of migrants and refugees. An EUI Forum on Migration, Citizenship and Demography

Publisher's note Springer Nature remains neutral with regard to jurisdictional claims in published maps and institutional affiliations. 